\title{
DETERMINATION OF VALUE AT RISK AND CONDITIONAL VALUE AT RISK BY ASSUMING ELLIPTICAL DISTRIBITION
}

\author{
[Stanovení Value at Risk a Conditional Value at Risk za předpokladu \\ eliptických rozdělení pravděpodobnosti]
}

\author{
Kateřina Zelinková ${ }^{1}$, Aleš Kresta ${ }^{2}$ \\ ${ }^{1}$ Vysoká škola báňská-Technická univerzita Ostrava, Ekonomická fakulta, Sokolská 33, 70121 Ostrava \\ Email:katerina.zelinkova@vsb.cz. \\ ${ }^{2}$ Vysoká škola báňská-Technická univerzita Ostrava, Ekonomická fakulta, Sokolská 33, 70121 Ostrava \\ Email:ales.kresta@vsb.cz
}

\begin{abstract}
The importance of risk management is nowadays one of the most important activities of financial institutions. One of the most commonly used methods for measuring and managing market risk is the indicator of Value at Risk (the minimum predicted loss for given significant level and time horizon) and Conditional Value at Risk (the average of expected losses that exceed the value of the Value at Risk). The aim of submitted article is the estimation of Value at Risk and Conditional Value at Risk for given shares of stock's portfolio assuming elliptical distribution of probability. Significant level is determined for $15 \%, 10 \%, 5 \%, 1 \%$ and $0.5 \%$ for time horizon one day. Firstly, fitting probability of time series will be estimated. It can be assumed that the least appropriate type of distribution for the time series will be the normal distribution. Next, VaR and CVaR will be calculated for all given probability distribution. Due to the fact that it is assumed that empirical time series and portfolio time series will correspond to either Student or Laplace distribution then the most appropriate model for estimating VaR and CVaR will be these two distributions.
\end{abstract}

Keywords: Conditional Value at Risk, Elliptical distribution, Laplace distribution, Student distribution, Value at Risk.

JEL classification: G11, G24

Doručeno redakci: 17.2.2016; Recenzováno: 29.2.2016; 11.4.2016; Schváleno k publikování: 24.8.2016

\section{Úvod}

Value at Risk (VaR) je nástrojem používaným od počátku 80. let minulého století řadou finančních institucí, který slouží k odhadování velikosti ztráty (hodnoty VaR), kterou může na trhu za nezměněných podmínek dosáhnout investor $\mathrm{s}$ určitou pravděpodobností $\mathrm{v}$ předem stanoveném období. Value at Risk je považován za základní měřítko pro kvantifikaci tržního, pojistného, nebo kreditního rizika, také se používá pro stanovení kapitálového požadavku v bankách či v pojišt’ovnách. Problematice Value at Risk je věnována řada publikací, ze kterých se vychází v daném článku, nejkomplexněji se obecně dané problematice věnuje Alexander (2008b), Hull (2007) a Jorion (2007). Artzner et al. (1999) charakterizoval tzv. Conditional Value at Risk (CVaR), jež lze definovat jako průměrnou velikost očekávaných ztrát, které převýší hodnotu Value at Risk. Jedná se o veličinu, která tedy vyjadřuje střední hodnotu ztráty v př́ipadě, že ztráta bude vyšší než hodnota Value at Risk. Tato veličina splňuje všechny axiomy koherentní míry rizika a z toho důvodu je více doporučována jako míra rizika než právě Value at Risk. Nicméně při měření rizikovosti finančních institucí se používá právě hodnota $\mathrm{VaR}$.

Tradiční rozdělení pravděpodobnosti pro výpočet Value at Risk analytickou metodou, jež bude aplikována $\mathrm{v}$ daném př́spěvku, se předpokládá normální rozdělení pravděpodobnosti. Nicméně, v praxi tento předpoklad platí jen zř́idka, protože konce rozdělení jsou silnější než 
u normálního rozdělení, protože empirické pravděpodobnostní rozdělení finančních výnosů má oproti normálnímu rozdělení vyšší špičatost a nenulovou šikmost, viz Fama (1965). Jednou z možných alternativ je použít Studentovo rozdělení pravděpodobnosti nebo Laplaceovo rozdělení pravděpodobnosti. Právě tato rozdělení náleží do tzv. eliptických rozdělení. Studentovo rozdělení má těžké konce a úzce souvisí s normovaným normálním rozdělením. Platí, že s rostoucím stupněm volnosti se k normálnímu rozdělení přibližuje. Pokud hodnota stupňů volnosti je větší než 30, tak se toto rozdělení považuje již za normální. Čím nižší je stupeň volnosti, tím nižší je vrchol křivky funkce hustoty a tím těžší jsou její konce. Laplaceovo (oboustranné exponenciální) rozdělení se vyskytuje v případech, kdy jsou náhodné veličiny měřeny za podmínek kolísání rozptylu kolem určité střrední hodnoty (Artl a Artlová, 2003). Ve srovnání s normálním rozdělením je Laplaceovo rozdělení špičatější a má delší konce.

Cílem př́spěvku je stanovit Value at Risk a Conditional Value at Risk pro akciové portfolio za předpokladu eliptických rozdělení, tzn. normálního, Studentovo a Laplaceovo rozdělení pravděpodobnosti a zjistit, jak se od sebe tyto hodnoty liší.

\section{Value at Risk a Conditional Value at Risk za předpokladu eliptických rozdělení}

Ukazatel Value at Risk je definován dle Zmeškala et al. (2004) jako nejmenší predikovaná ztráta na dané hladině pravděpodobnosti za daný časový interval. Také lze charakterizovat Value at Risk jako jednostranný interval spolehlivosti potencionálních ztrát hodnoty portfolia po danou dobu držení, což lze zapsat:

$$
F(x)=P\left(X \leq-\operatorname{VaR}_{\alpha, \Delta t}(x)\right)=\alpha
$$

kde $F(x)$ je distribuční funkce, $\alpha$ je hladina spolehlivosti and $\Delta t$ je časový horizont.

Normální rozdělení je v praxi značně využíváno díky svým vlastnostem, zejména jednoduchosti, která spočívá v potřebě pouze dvou snadno zjistitelných parametrů $\left(\mu, \sigma^{2}\right)$. Normální rozdělení pravděpodobnosti je jedním z nejznámějších rozdělení pravděpodobností spojité náhodné veličiny. Náhodná proměnná $X$ má normální rozdělení, jestliže se funkce hustoty rovná (Alexander, 2008a),

$$
\varphi(X)=\frac{1}{\sqrt{2 \pi \sigma^{2}}} \exp \left[-\frac{(x-\mu)}{2 \sigma^{2}}\right],
$$

kde $\mu=E(x)$ zobrazuje střední hodnotu, $\sigma^{2}$ vyjadřuje rozptyl a náhodná proměnná $x$ nabývá hodnot $\mathrm{z}$ intervalu $(-\infty ; \infty)$. Při odhadu parametrů daného rozdělení je použita metoda maximální věrohodnosti. Normální rozdělení má zásadní význam, protože mnoho náhodných veličin v oblasti ekonomie bud' mají normální rozdělení, nebo lze rozdělení těchto náhodných veličin normálním rozdělením alespoň aproximovat. Normální rozdělení má použití všude tam, kde je kolísání náhodné veličiny způsobeno součtem velkého počtu nepatrných vzájemně nezávislých vlivů. Vztah pro výpočet Value at Risk za předpokladu normálního rozdělení má tvar

$$
\operatorname{VaR}=\Phi^{-1}(\alpha) \cdot \sigma-\mu
$$

kde $\Phi^{-1}$ je inverzní funkce $\mathrm{k}$ distribuční funkci normovaného normálního rozdělení, $\alpha$ je hladina významnosti, $\sigma$ je směrodatná odchylka, $\mu$ střední hodnota.

Studentovo $t$-rozdělení je kontinuální rozdělení pravděpodobnosti, kterým lze vyčíslit střední hodnotu a normální distribuci populace. Lze jej použít za předpokladu, že daný vzorek údajů 
je malý (Cipra, 2008). Studentovo $t$-rozdělení úzce souvisí s normovaným normálním rozdělením a s rostoucím stupněm volnosti se k normálnímu rozdělení přibližuje. Pokud je $v \geq$ 30, tak se toto rozdělení již považuje za normální. Čím nižší je stupeň volnosti, tím vyšší je vrchol křivky funkce hustoty a tím těžší jsou její konce. Funkce hustoty pro Studentovo $t$ rozdělení $\mathrm{s} v$ stupni volnosti je definována následujícím vztahem (Lewis, 2003),

$$
f_{v}(t)=(v \pi)^{\frac{-1}{2}} \Gamma\left(\frac{v}{2}\right)^{-1} \Gamma\left(\frac{v+1}{2}\right)\left(1+\frac{t^{2}}{v}\right)^{-\left(\frac{v+1}{2}\right)},
$$

kde gamma funkce $\Gamma$ je rozšîřením funkce faktoriálu $n$ ! na neceločíselné hodnoty. Náhodná proměnná, která má Studentovo $t$-rozdělení, se značí $\mathbf{T} \sim \mathbf{t}_{\mathbf{V}}$. Věrohodnostní funkce Studentova rozdělení vychází z funkce hustoty (4) a je dána

$$
L\left(x_{1}, x_{2}, \ldots, x_{n} \mid \theta_{1}, \theta_{2}, \ldots \theta_{k}\right)=\prod_{i=1}^{N}(v \pi)^{\frac{-1}{2}} \Gamma\left(\frac{v}{2}\right)^{-1} \Gamma\left(\frac{v+1}{2}\right)\left(1+\frac{t^{2}}{v}\right)^{-\left(\frac{v+1}{2}\right)} .
$$

Nyní se věrohodnostní funkce zlogaritmuje a pomocí optimalizační úlohy, jež se maximalizuje, se stanoví stupně volnosti

$$
L=\left[\ln (v \pi)^{\frac{-1}{2}}-\ln \Gamma\left(\frac{v}{2}\right)^{-1}-\frac{1}{2} \ln \pi v-\ln \sigma\right]-\left(\frac{v+1}{2}\right) \sum \log \left(1+\left(1+\frac{x_{i}-\mu}{\sigma \sqrt{v}}\right)^{2}\right),
$$

Vztah pro výpočet Value at Risk za předpokladu Studentova rozdělení pravděpodobnosti je následující

$$
V a R=\sqrt{v^{-1}(v-2)} t^{-1}(\alpha) \sigma-\mu .
$$

Laplaceovo rozdělení se vyskytuje $\mathrm{v}$ případech, kdy jsou náhodné veličiny měřeny za podmínek kolísání rozptylu kolem určité střední hodnoty. Ve srovnání s normálním rozdělením je Laplaceovo rozdělení špičatější a má delší konce. Funkce hustoty pro Laplaceovo rozdělení pravděpodobnosti je dána (Beirlant et al., 2004),

$$
f(x)=\frac{1}{2 \sigma} \exp \left(-\frac{|x-\mu|}{\sigma}\right),
$$

kde $\mu$ zobrazuje střední hodnotu, $\sigma>0$ vyjadřuje směrodatnou odchylku a náhodná proměnná x nabývá hodnot $\mathrm{z}$ intervalu $(-\infty ; \infty)$. Laplaceovo rozdělení se $\mathrm{v}$ literatuře objevuje často jako jedna z forem obecnějších rozdělení doporučovaných pro popis chování finančních časových řad. A připouští výskyt výrazněji odchýlených hodnot a využivá se jako „robustní“ alternativa normálního rozdělení. Pro výpočet hodnoty Value at Risk portfolia akcií za předpokladu Laplaceova rozdělení pravděpodobnosti, lze využít následující vztah

$$
\operatorname{VaR}=-\frac{1}{\sqrt{2}} \cdot \ln (2 \alpha) \sigma .
$$

Conditional Value at Risk (CVaR) se také nazývá Expected Shortfall $(E S)$ nebo Expected Tail Loss $(E T L)$. Conditional Value at Risk lze definovat jako průměrnou velikost očekávaných ztrát, které převýší hodnotu Value at Risk. Jedná se o veličinu, která tedy vyjadřuje střední hodnotu ztráty v prŕípadě, že ztráta bude vyšší než hodnota Value at Risk. Tedy hodnota CVaR je vždy vyšší než hodnota VaR. Matematicky lze CVaR vyjádřit následovně 


$$
C \operatorname{VaR}_{\alpha}(X)=-E\left(X / X<\operatorname{VaR}_{\alpha}\right),
$$

kde $V_{a} R_{\alpha}$ je očekávaná ztráta, $X$ je náhodná veličina vyjadřující zisk či ztrátu a představuje hodnotu VaR na hladině významnosti $\alpha$. Hodnota CVaR má lepší vypovídací schopnost než VaR, protože splňuje všechny čtyři podmínky pro koherentní míru rizika, které jsou monotónost, subadditivita, homogenita a translační invariance. Vzhledem k tomu, že CVaR udává konkrétní hodnotu ztráty př̌i překročení hladiny neočekávané ztráty, umožňuje riziko popsat komplexněji než při použití VaR.

Výpočet pro hodnotu Conditional Value at Risk za předpokladu normálního rozdělení má tvar

$$
C V a R=\alpha^{-1}\left[\frac{1}{\sqrt{2 \pi}} \exp \left(-\frac{1}{2} z^{2}\right)\right]_{-\infty}^{\phi^{-1}(\alpha)} .
$$

Vztah pro výpočet $\mathrm{CVaR}$ za predpokladu Studentova rozdělení pravděpodobnosti je následující

$$
\operatorname{CVaR}_{h, \alpha, v}(t)=\alpha^{-1}(v-1)^{-1}\left(v-2+x_{\alpha}(v)^{2}\right) f_{v}\left(x_{\alpha}(v)\right) \sigma-\mu .
$$

Vztah pro výpočet CVaR za předpokladu Laplaceova rozdělení (Zhuo et al, 2014) je následující

$$
C \operatorname{VaR}=(1-\ln \alpha) g(\mu, \tau)-g(\mu, \tau) \ln \left(2+\frac{\mu}{g(\mu, \tau)}\right)
$$

kde $g(\mu, \tau)$ je definováno jako $g(\mu, \tau)=\tau^{2} /\left(\mu+\sqrt{\mu^{2}+2 \tau^{2}}\right)$ a $\tau^{2}$ lze jednoduše analyticky zjistit jako $\tau^{2}=\sigma^{2}-\mu^{2}$.

\section{Stanovení VaR a CVaR pro portfolio aktiv}

Metodologie Value at Risk a prístup Conditional Value at Risk budou aplikovány na akciové portfolio, které je sestaveno deseti nejvíce obchodovatelných akcií na americkém trhu v druhém kvartálu tohoto roku. Nejprve jsou popsána a analyzována vstupní data. Dále je $\mathrm{z}$ těchto akcií sestaveno portfolio, přičemž váhy jednotlivých akcií v portfoliu jsou stejné, tzn. 0,1. Pro dané portfolio aktiv je stanovena hodnota Value at Risk a Conditional Value at Risk pro různé stupně pravděpodobnosti.

\subsection{Popis a analýza empirických dat}

Ceny akcií byly zjišt'ovány za období od ledna 2009 do listopadu 2015. Za toto období je k dispozici 1931 denních závěrečných kurzů pro každou akcii. Ceny akcií byly zjišt’ovány $\mathrm{z}$ databáze portálu www.financialyahoo.com. Portfolio je složeno z deseti titulů, znamená to, že je také vystaveno deseti rizikovým faktorům, které jsou představovány cenami jednotlivých akcií.

Po zjištění potřebných informací o daném portfoliu a sestavení časových řad vývoje cen jednotlivých akcií byla vypočtena další data, potřebná pro výpočet hodnoty Value at Risk. Těmito daty byly denní výnosy těchto akcií. Tyto denní výnosy byly vypočteny spojitě. Z 1931 denních kurzů bylo vypočteno 1930 denních spojitých výnosů dle vztahu

$$
R=\ln \frac{P_{t}}{P_{t-1}}
$$


kde $R$ je výnos, $P_{t}$ je cena akcie $\mathrm{v}$ čase $t$ a $P_{t-1}$ je cena $\mathrm{v}$ čase $t-1$. Nejprve byly vypočteny logaritmické výnosy dle vztahu (13). Výpočty základních charakteristik jednotlivých výnosů jsou zobrazeny $\mathrm{v}$ následující tabulce.

Tabulka 1: Základní charakteristiky akcií

\begin{tabular}{|l|l|l|l|l|l|l|l|}
\hline & $\mathrm{N}$ & $\begin{array}{l}\text { Střední } \\
\text { hodnota }\end{array}$ & $\begin{array}{l}\text { Směrodatná } \\
\text { odchylka }\end{array}$ & Šikmost & Špičatost & Min & Max \\
\hline Apple & 1930 & $0,071 \%$ & $2,119 \%$ & $-0,5402$ & 7,6997 & $-19,7 \%$ & $13,0 \%$ \\
\hline Applied_Material & 1930 & $-0,005 \%$ & $2,228 \%$ & $-0,1660$ & 4,1976 & $-13,5 \%$ & $13,3 \%$ \\
\hline Cisco & 1930 & $-0,002 \%$ & $2,008 \%$ & $-0,4254$ & 11,5480 & $-17,7 \%$ & $14,8 \%$ \\
\hline Fox & 1930 & $0,015 \%$ & $2,499 \%$ & $\mathbf{0 , 1 5 0 2}$ & 8,5069 & $-17,0 \%$ & $18,9 \%$ \\
\hline Intel & 1930 & $0,004 \%$ & $1,954 \%$ & $-0,0627$ & 4,9276 & $-13,2 \%$ & $11,2 \%$ \\
\hline Micron & 1930 & $0,042 \%$ & $3,798 \%$ & $-0,1795$ & 4,1461 & $-20,3 \%$ & $21,1 \%$ \\
\hline Microsoft & 1930 & $0,010 \%$ & $1,864 \%$ & $\mathbf{0 , 1 2 4 0}$ & 9,3175 & $-12,5 \%$ & $17,1 \%$ \\
\hline Powershares & 1930 & $0,037 \%$ & $1,433 \%$ & $-0,0717$ & 7,3196 & $-9,4 \%$ & $11,5 \%$ \\
\hline Sirius & 1930 & $-0,016 \%$ & $3,906 \%$ & $-0,4864$ & 8,8690 & $-26,8 \%$ & $22,3 \%$ \\
\hline Yahoo & 1930 & $-0,002 \%$ & $2,406 \%$ & $-0,7309$ & 8,7683 & $-23,4 \%$ & $11,3 \%$ \\
\hline
\end{tabular}

Zdroj: vlastní výpočty na základě dat $\mathrm{z}$ www.financialyahoo.com

Dle Tabulky 1 lze vidět vypočtené základní vstupní parametry, jako jsou střední hodnota, směrodatná odchylka, šikmost a špičatost. Je zřejmé, že střední hodnota a směrodatná odchylka výnosů se pohybují kolem nuly. Koeficient šikmost neboli třetí centrální normovaný moment může být kladný nebo záporný podle toho, na kterou stranu jsou odchylky od střední hodnoty větší. Pokud je křivka hustoty pravděpodobnosti symetrická vzhledem ke střední hodnotě, je koeficient šikmosti nulový. Míry šikmosti poukazují na asymetrické rozdělení výnosů, a to levostranné, tedy mimo akcii FOX a MICROSOFT, v jejímž př́padě není hodnota záporná, ale kladná.

Koeficient špičatosti neboli čtvrtý centrální normovaný moment charakterizuje rozdělení finančního instrumentu a porovnává dané rozdělení $\mathrm{s}$ normálním rozdělením pravděpodobnosti. Pro normální rozdělení pravděpodobnosti by byl koeficient špičatosti roven třem. V př́padě výsledku většího než tři jsou odchylky od stř̌ední hodnoty větší než u normálního rozdělení. Na základě Tabulky 1 lze také pozorovat, že špičatost výnosů akcií je o poznání vyšší, než je charakteristické pro normální rozdělení (hodnota by měla být nulová). Již z pohledu na hodnoty koeficientu šikmosti a špičatosti je zřejmé, že normální rozdělení není vhodné pro modelování těchto časových řad. Toto lze potvrdit i pomocí Kolgomorov Smirnova testu (K-S test), viz Tabulka 2, pomocí kterého můžeme pro všechny časové řady na $1 \%$ hladině pravděpodobnosti zamítnout nulovou hypotézu, že řady odpovídají normálnímu rozdělení. 
Tabulka 2: Kolmogorov Smirnovův test

\begin{tabular}{|l|c|c|c|r|}
\hline & & Normální & Studentovo & Laplaceovo \\
\hline & $d f$ & Sig. & Sig. & \multicolumn{1}{c|}{ Sig. } \\
\hline Apple & 1930 & 0,000 & $\mathbf{0 , 0 1 1}$ & $\mathbf{0 , 0 3 3}$ \\
\hline Applied_Material & 1930 & 0,000 & 0,009 & $\mathbf{0 , 0 2 1}$ \\
\hline Cisco & 1930 & 0,000 & 0,002 & $\mathbf{0 , 0 1 1}$ \\
\hline Fox & 1930 & 0,000 & 0,002 & 0,01 \\
\hline Intel & 1930 & 0,000 & $\mathbf{0 , 0 1 4}$ & $\mathbf{0 , 0 3 4}$ \\
\hline Micron & 1930 & 0,000 & $\mathbf{0 , 0 4 9}$ & $\mathbf{0 , 0 6 5}$ \\
\hline Microsoft & 1930 & 0,000 & $\mathbf{0 , 0 1 2}$ & $\mathbf{0 , 0 1 9}$ \\
\hline Powershares & 1930 & 0,000 & $\mathbf{0 , 0 6 5}$ & $\mathbf{0 , 0 7}$ \\
\hline Sirius & 1930 & 0,000 & 0,001 & 0,008 \\
\hline Yahoo & 1930 & 0,000 & 0,004 & $\mathbf{0 , 0 4}$ \\
\hline
\end{tabular}

Zdroj: vlastní výpočty v programu SPSS

$H_{0}$ : soubor má dané rozdělení pravděpodobnosti

$H_{1}$ : soubor nemá dané rozdělení pravděpodobnosti
Sig. > 0,01 (tučně zvýrazněné)

Sig. $<0,01$

V prrípadě normálního rozdělení se zamítá nulová hypotéza dle $p$-hodnoty, tedy dané časové řady nesplňují předpoklad normálního rozdělení pravděpodobnosti. $P$-hodnota $(S i g)<.\alpha$, tzn. že $p$-hodnota, která je prezentována jako Sig. je menší než zvolená hladina pravděpodobnosti $1 \%$. V př́padě Studentova a Laplaceova rozdělení pravděpodobnosti není zamítnuta nulová hypotéza ve všech případech. Dané časové řady odpovídají většinou Laplaceovu rozdělení pravděpodobnosti.

\subsection{Výpočet VaR a CVaR pro akciové portfolio}

Portfolio je složeno z deseti akcií, jež jsou analyzovány v předchozí kapitole. Předpokládá se, že váhy akcií v portfoliu jsou stejné.

Tabulka 3: Základní charakteristiky portfolia

\begin{tabular}{|r|c|c|c|c|c|c|}
\hline & $\begin{array}{r}\text { Střední } \\
\text { hodnota }\end{array}$ & $\begin{array}{r}\text { Směrodatná } \\
\text { odchylka }\end{array}$ & Šikmost & Špičatost & Minimum & Maximum \\
\hline Portfolio & $0,03 \%$ & $1,423 \%$ & $-0,036$ & 7,677 & $-9 \%$ & $12 \%$ \\
\hline
\end{tabular}

Zdroj: vlastní výpočty

V Tabulce 3 lze vidět vypočtené základní vstupní parametry, jako jsou střední hodnota, směrodatná odchylka, šikmost a špičatost. Je zřejmé, že střední hodnota a směrodatná odchylka výnosů se pohybují kolem nuly. Koeficient šikmosti poukazuje na asymetrické rozdělení výnosů, a to levostranné. Koeficient špičatosti je vyšší, než je charakteristické pro normální rozdělení. Z třetího a čtvrtého centrálního momentu je zrejmé, že normální rozdělení není vhodné pro modelování daného portfolia. Toto lze potvrdit i pomocí K-S testu, jež výsledky pro portfolio jsou zobrazeny v Tabulce 4.

Tabulka 4: K-S test portfolia

\begin{tabular}{|c|c|c|c|}
\hline & Normální & Studentovo & Laplaceovo \\
\hline & Sig. & Sig. & Sig. \\
\hline Portfolio & 0,000 & 0,0269 & 0,062 \\
\hline
\end{tabular}

Zdroj: vlastní výpočty 
V př́ípadě normálního rozdělení se zamítá nulová hypotéza dle $p$-hodnoty (Sig.), tedy portfolio nesplňuje předpoklad normálního rozdělení pravděpodobnosti. Vzhledem k tomu, že vstupní data odpovídala převážně Laplaceovu rozdělení, se předpokládá, že dané portfolio věrohodně popisuje také právě Laplaceovo rozdělení, což se potvrdilo. Portfolio má Studentovo rozdělení na hladině pravděpodobnosti $1 \%$ a Laplaceovo rozdělení má dokonce při $5 \%$. Dále byly provedeny QQ ploty.

Obrázek 1: QQ ploty portfolia
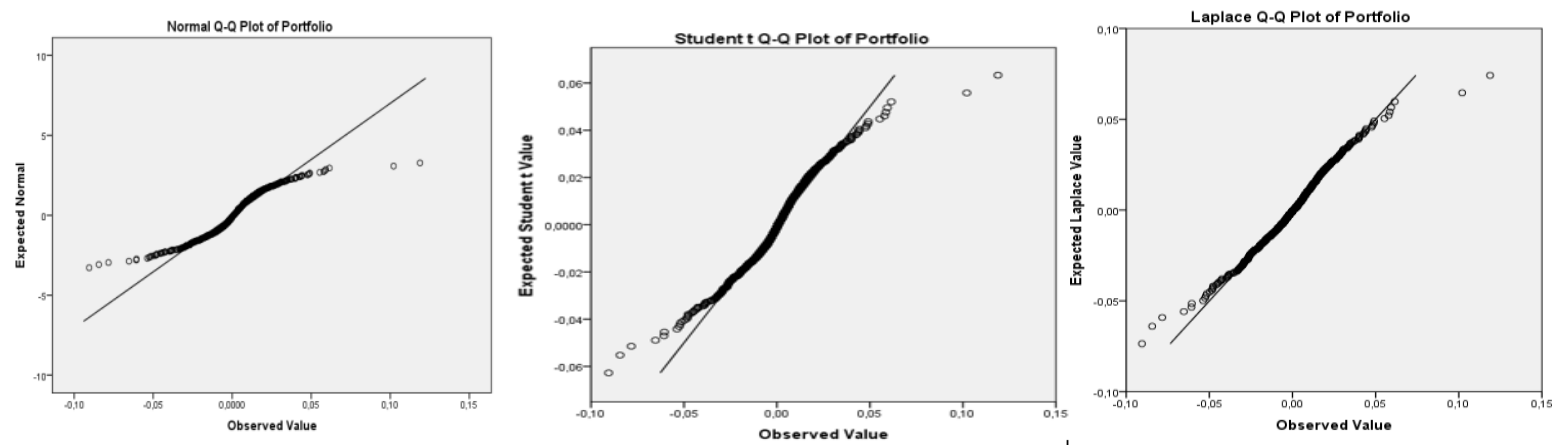

Zdroj: vlastní zpracování v SPSS

Podle QQ plotů se ukázalo, že normální rozdělení pravděpodobnosti nepopisuje věrohodně empiricky napozorovaná data. Nasbíraná data vykazují těžší konce rozdělení oproti zkoumaným teoretickým rozdělením pravděpodobnosti. $Z$ toho důvodu je vhodné stanovit VaR a CVaR pomocí jiných typů rozdělení, které akceptují těžší konce rozdělení. Mezi takové přístupy patří právě použití Studentovo rozdělení a Laplaceovo rozdělení. V př́ípadě QQ plotu pro Studentovo rozdělení lze vidět, že konce nepřiléhají teoretickému rozdělení pravděpodobnosti. $Z$ toho důvodu není vhodné používat ani Studentovo rozdělení. Nejlépe odpovídá empirické rozdělení s teoretickým rozdělením právě u QQ plotu Laplaceova rozdělení a to i přesto, že některé hodnoty zcela nedoléhají.

Nyní se odhadne hodnota VaR a CVaR za předpokladu normálního, Studentova a Laplaceova rozdělení pro stanovené portfolio aktiv. I když testování normality ukázalo, že dané portfolio neodpovídá věrohodně normálnímu ani Studentovu rozdělení, tak i přesto je vypočtena hodnota $\mathrm{VaR}$ a CVaR za předpokladu těchto dvou typů rozdělení a to z toho důvodu, aby bylo zřejmé, jaká chyba může nastat při nevhodném použití rozdělení pravděpodobnosti. Nejprve se musí odhadnout parametry vztahů $\mathrm{VaR}$ a $\mathrm{CVaR}$ za předpokladu všech uvedených rozdělení pravděpodobnosti. Jednotlivé parametry pro portfolio vychází z Tabulky 3, ovšem chybí jeden parametr a to stupně volnosti pro Studentovo rozdělení. Stupně volnosti se odhadnou pomocí metody maximální věrohodnosti za pomocí optimalizační úlohy, kdy je použit vztah (5).

Tabulka 5: Odhad stupňů volnosti

\begin{tabular}{|l|l|}
\hline & Portfolio \\
\hline Stupně volnosti $-v$ & 4,70 \\
\hline Logaritmická funkce & $-527,81$ \\
\hline Zdroj: vlastní výpočty
\end{tabular}

Nyní jsou známy všechny parametry, a tudíž se může přejít k samotnému výpočtu hodnoty VaR a CVaR. Hladina významnosti je stanovena ve výši $15 \%, 10 \%, 5 \%, 1 \%$ a $0,5 \%$. Časový horizont je jeden den. $\mathrm{V}$ následující tabulce jsou ukázány vypočítané hodnoty VaR 
za předpokladu normálního rozdělení dle (3), za předpokladu Studentova rozdělení dle vztahu (6), přičemž stupně volnosti jsou uvedeny v Tabulce 5 a Laplaceova rozdělení dle rovnice (8).

Tabulka 6: Odhad hodnoty VaR

\begin{tabular}{|l|l|l|l|l|l|}
\hline & $\mathbf{1 5 \%}$ & $\mathbf{1 0 \%}$ & $\mathbf{5 \%}$ & $\mathbf{1 \%}$ & $\mathbf{0 , 5 \%}$ \\
\hline Normální & $1,78 \%$ & $2,20 \%$ & $2,83 \%$ & $4,00 \%$ & $4,43 \%$ \\
\hline Studentovo & $1,54 \%$ & $1,99 \%$ & $2,77 \%$ & $4,87 \%$ & $5,99 \%$ \\
\hline Laplaceovo & $1,46 \%$ & $1,96 \%$ & $2,80 \%$ & $4,75 \%$ & $\mathbf{5 , 6 0 \%}$ \\
\hline
\end{tabular}

Zdroj: vlastní výpočty

Z Tabulky 6 je patrné, že hodnota VaR pro portfolio za předpokladu Laplaceova rozdělení a hladiny významnosti $0,5 \%$ je ve výši $5,6 \%$, což znamená, že za předpokladu hladiny významnosti $0,5 \%$ bude predikovaná ztráta větší nebo rovna právě 5,6 \% z hodnoty daného portfolia. Vzhledem $\mathrm{k}$ tomu, že odhad vhodného typu rozdělení pro portfolio je právě model s Laplaceovým rozdělením, lze očekávat, že tato hodnota je „nejlepší“. V případě použití normálního rozdělení by byla predikovaná ztráta podhodnocena, tzn., že by finanční instituce držely nižší obnos peněz, než očekávaly. Naopak, při použití modelu VaR se Studentovým rozdělením, je hodnota VaR nadhodnocena, tzn., že by finanční instituce držely větší množství peněz. Dosažené hodnoty Value at Risk z Tabulky 6 jsou pro lepší názornost zobrazeny do grafu, viz obrázek 2. Jak je v tomto grafu znázorněno, hodnota VaR s rostoucí pravděpodobností nepřekročení této ztráty roste.

Obrázek 2: Hodnoty VaR pro portfolio při využití různých hladinách významnosti

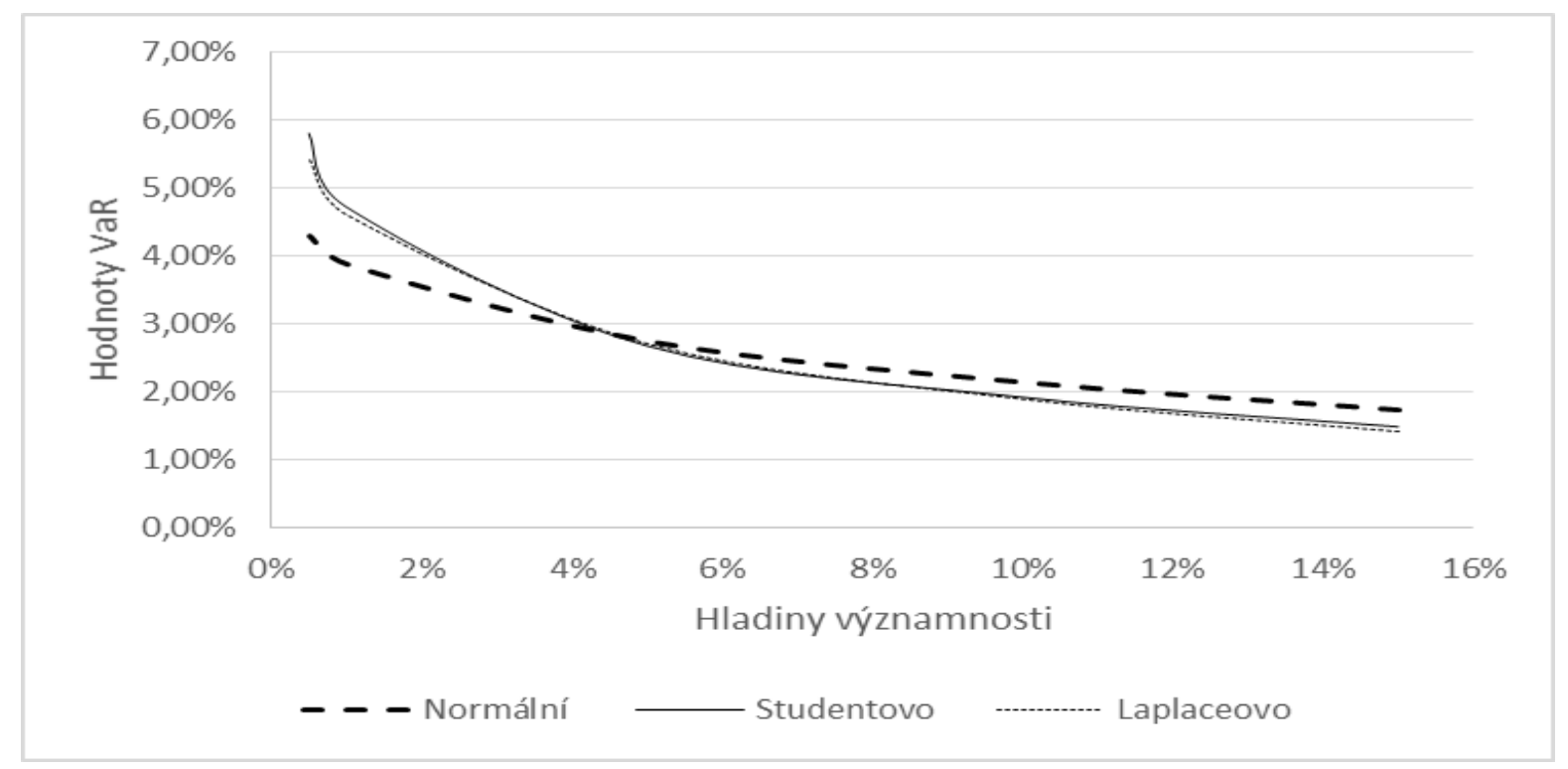

Zdroj: vlastní zpracování

V Obrázku 2 lze názorně vidět rozdíly hodnot VaR za předpokladu různých rozdělení pravděpodobnosti při daných hladinách významnosti. Křivka, která znázorňuje hodnotu VaR za předpokladu Studentova rozdělení, je téměř totožná s křivkou, která znázorňuje hodnoty VaR za předpokladu Laplaceova rozdělení pravděpodobnosti. 
Také byly vypočítány hodnoty pro CVaR za předpokladu normálního rozdělení dle (10), Studentova rozdělení dle vztahu (11) a Laplaceova rozdělení pravděpodobnosti (12). Hodnoty jsou uvedeny v Tabulce 7 .

Tabulka 7: Odhad hodnoty CVaR

\begin{tabular}{|c|c|c|c|c|c|}
\hline & $\mathbf{1 5 \%}$ & $\mathbf{1 0 \%}$ & $\mathbf{5 \%}$ & $\mathbf{1 \%}$ & $\mathbf{0 , 5 \%}$ \\
\hline Normální & $2,67 \%$ & $3,02 \%$ & $3,54 \%$ & $4,58 \%$ & $4,97 \%$ \\
\hline Studentovo & $3,00 \%$ & $3,69 \%$ & $4,89 \%$ & $7,54 \%$ & $8,56 \%$ \\
\hline Laplaceovo & $2,20 \%$ & $2,61 \%$ & $3,31 \%$ & $4,92 \%$ & $\mathbf{5 , 6 1 \%}$ \\
\hline
\end{tabular}

Zdroj: vlastní výpočty

Z definice CVaR vyplývá, že hodnoty CVaR by měly být vyšší než hodnoty VaR, což pro všechny vypočtené modely platí. Hodnota $\mathrm{CVaR}$ za předpokladu Laplaceova rozdělení pravděpodobnosti pro hladinu významnosti $0,5 \%$ znamená, že střední hodnota ztráty v případě, že ztráta bude vyšší než hodnota Value at Risk je ve výši 5,61 \%. Vzhledem $\mathrm{k}$ tomu, že časová řada daného portfolio nejlépe odpovídala Laplaceovu rozdělení, lze očekávat, že tato hodnota je „nejlepší“. V př́ípadě použití normálního rozdělení by byla predikovaná ztráta podhodnocena, tzn., že by finanční instituce držely nižší obnos peněz, než očekávaly. Naopak, při použití modelu VaR se Studentovým rozdělením, je hodnota VaR nadhodnocena, tzn., že by finanční instituce držely větší množství peněz. Opět pro lepší orientaci jsou hodnoty CVaR znázorněny graficky, viz Obrázek 3.

Obrázek 3: Hodnoty CVaR pro portfolio při využití různých hladinách významnosti

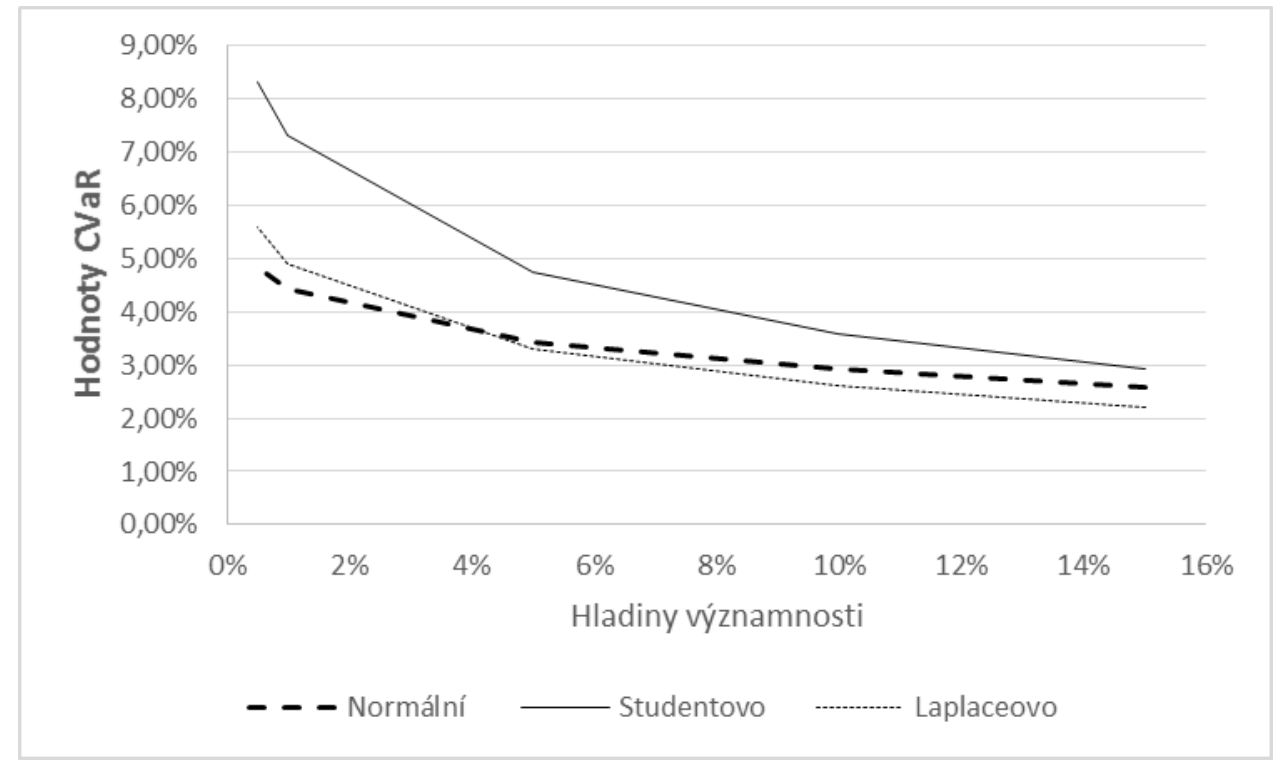

Zdroj: vlastní zpracování

Z Obrázku 3 je zřejmé, že hodnoty CVaR za předpokladu Studentova a Laplaceova rozdělení pro různé hladiny pravděpodobnosti nejsou téměř totožné jako v případě hodnot VaR. S rostoucí hladinou významnosti klesá hodnota CVaR pro všechny uvedené modely. Nejvyšší hodnoty CVaR dosahují modely za předpokladu Studentova rozdělení pravděpodobnosti pro všechny hladiny významnosti a naopak nejnižší hodnoty CVaR jsou za předpokladu Laplaceova rozdělení pravděpodobnosti a to pro hladiny významnosti $15 \%$, $10 \%$ a $5 \%$. 


\subsection{Diskuse}

Fama (1965) uvedl ve svém článku, že výnosy nemají normální rozdělení, vykazují vyšší špičatost a těžší konce, což odpovídá i výsledkům v tomto článku. Právě pro výnosy s vyšší špičatostí a těžšími konci lze očekávat, že mohou splňovat právě Studentovo nebo Laplaceovo rozdělení pravděpodobnosti. $Z$ deseti uvedených akcií dle K-S testu právě pět splňuje Studentovo rozdělení pravděpodobnosti a osm časových řad Laplaceovo rozdělení. Vzhledem k tomu, že u všech uvedených časových řad není přijata nulová hypotéza, tak je vhodné ověřovat další typy rozdělení pravděpodobnosti pro empiricky napozorovaná data, např̀. NIG rozdělení.

Jak lze vidět z výsledků odhad hodnoty VaR, viz Tabulka 6 , tak míra rizika za předpokladu normálního rozdělení je vyšší při vyšších hladinách významnosti. Při 5\% hladině významnosti se dané hodnoty při různých typech pravděpodobnosti neliší a při nižších než $5 \%$ hladině významnosti jsou hodnoty VaR za předpokladu Studentova a Laplaceova rozdělení naopak vyšší než za předpokladu normálního rozdělení. Výsledky VaR za předpokladu Studentova a Laplaceova rozdělení pravděpodobnosti se výrazně neliší za všech uvedených hladin významnosti, $\mathrm{z}$ toho důvodu je vhodné provést verifikaci daných modelů. Alexander $(2008 \mathrm{~b})$ ve své publikaci dochází ke stejným výsledkům při ilustrativním př́kladu na srovnání hodnoty VaR za předpokladu normálního a Studentova rozdělení. Stejný průběh výsledků při daných hladinách významnosti je i při odhadu hodnoty CVaR, viz Tabulka 7.

\section{Závěr}

Cílem daného článku bylo stanovit Value at Risk a Conditional Value at Risk pro akciové portfolio za předpokladu eliptických rozdělení, tzn. normálního, Studentovo a Laplaceovo rozdělení pravděpodobnosti a zjistit, jak se od sebe tyto hodnoty liší. Nejprve byl proveden K$\mathrm{S}$ test jednotlivých časových řad, tzn. výnosů jednotlivých akcií, kde se zjistilo, že časové řady na hladině pravděpodobnosti $1 \%$ nemají normální rozdělení, Studentovu rozdělení odpovídají pět akcií a Laplaceovo rozdělení věrohodně popisuje osm časových řad. Dále byl proveden stejný test pro dané portfolio. Portfolio nejlépe popisuje Laplaceovo rozdělení pravděpodobnosti na hladině pravděpodobnosti $5 \%$ a na hladině pravděpodobnosti $1 \%$ odpovídá portfolio i Studentovu rozdělení. Z toho důvodu se předpokládá, že nejvhodnější model stanovení VaR a CVaR je právě za předpokladu Laplaceova rozdělení. I presto byla vypočtena hodnota $\mathrm{VaR}$ a $\mathrm{CVaR}$ za předpokladu normální a Studentova rozdělení, aby se dané hodnoty mohly porovnat a ilustrovat velikost chyby při nevhodném použití modelu.

V prŕípadě použití normálního rozdělení by byla predikovaná ztráta podhodnocena oproti hodnotě VaR za předpokladu Laplaceova rozdělení pravděpodobnosti při nižších hladinách významnosti $(0,5 \%$ a $1 \%)$ tzn., že by finanční instituce držely nižší obnos peněz, než očekávaly. Při vyšších hladinách významnosti tomu bylo naopak. Při použití modelu VaR se Studentovým rozdělením, je hodnota $\mathrm{VaR}$ nadhodnocena, za předpokladu nižších hladin významnosti $(0,5 \%$ a $1 \%)$, tzn., že by finanční instituce držely větší množství peněz. Pro lepší názornost byly výsledky graficky zobrazeny.

\section{Poděkování}

Tento článek vznikl za podpory projektu grantu - GP13-18300P „Modelování finančních časových řad a odhad rizika“.

\section{Literatura}

[1] ALEXANDER, C., 2008a. Quantitave Methods in Finance. Chichester: John Wiley\& Sons. ISBN 978-0-470-99788-8. 
[2] ALEXANDER, C., 2008b. Value at Risk models. Chichester: John Wiley\& Sons, ISBN 978-0-470-99800-7.

[3] ARTL, J. a M. ARTLOVÁ, 2003. Finanční časové rady. Praha: Grada. ISBN 80-2470330-0.

[4] ARTZNER, P., F. DELBAEN, J.-M. EBER a D. HEATH, 1999. Coherent measures of risk. Mathematical finance, 9(3), 203-228. ISSN 1467-9965.

[5] BEIRLANT, J., Y. GOEGEBEUR, J. SEGERS a J. TEUGELS, 2004. Statistics of Extremes: Theory and Applications. Chichester: John Wiley\& Sons. ISBN 978-0-47197647-9.

[6] CIPRA, T., 2008. Finanční ekonometrie. Praha: Ekopress. ISBN 978-80-86929-43-9.

[7] FAMA, E. F., 1965. The behavior of stock market prices. Journal of Business, 38(1), 34105. ISSN 0021-9398.

[8] HULL, J., 2007 Risk Management and Financial Institutions. New Jersey: Pearson Education. ISBN 013-239790-6.

[9] JORION, P., 2007. Value at Risk: The New Benchmark for Managing Financial Risk. 2. vyd. New York: McGraw-Hill. ISBN 978-0-07-146495-6.

[10] LEWIS, N., 2003. Market Risk Modelling. London: Risk Books. ISBN 1-904339-07-7.

[11] ZHUO, S., Q. LU, L. HAN, Y. LIU a F. HU, 2014. A mean-CVaR-skewness portfolio optimization model based on asymmetric Laplace distribution. Annals of Operations Research, 226(1), 727-739. ISSN 1572-9338.

[12] ZMEŠKAL, Z. et al., 2004. Financial models. Ostrava: VŠB - TU Ostrava. ISBN 8086119-87-4. 